\title{
REGULAR ARTICLE \\ VARIATION IN NUTRITIONAL VALUE OF GREWIA TENAX FRUITS FROM DIFFERENT REGIONS OF RAJASTHAN, INDIA \\ MALA RATHORE*
}

Non-Wood Forest Products Division, Arid Forest Research Institute, Jodhpur, India

\begin{abstract}
In the present investigation, an attempt has been made to identify the variation in nutritional value of Grewia tenax fruits from different regions of Rajasthan, India. Fruits were collected from Jodhpur (Kailana, Bilara) and Barmer (Siwana) region and analyzed nutritionally. Maximum ash and vitamin C content was obtained in samples from Siwana $(4.73 \%$ and $56.47 \%$ respectively). Maximum fat content (2.66 \%) was obtained in samples from Bilara. Maximum sugar and protein content was obtained in samples from Kailana (35.51\% and 8.4\% respectively). They are rich in vitamin C (39 mg/100 gm) content. The fruits are also rich sources of minerals such as $\mathrm{Ca}(0.32 \pm 0.03 \mathrm{~g} / 100 \mathrm{~g}), \mathrm{K}(1.26 \pm 0.31 \mathrm{~g} / 100 \mathrm{~g})$ and $\mathrm{Na}(1.49 \pm 0.32 \mathrm{~g} / 100 \mathrm{~g})$ than the cultivated crop plants. Trace elements such as $\mathrm{Fe}, \mathrm{Zn}, \mathrm{Cu}, \mathrm{Mn}$ and $\mathrm{Mg}$ were also analyzed. These results of nutritional composition were compared with those collected from Bilara and Siwana area of Jodhpur region. Many medicinal applications of G. tenax viz. as remedy for colds and chest complaints have also been reported. Thus, the importance of $G$. tenax in the rural economy is highly significant.
\end{abstract}

Keywords: Sugar, Protein, Nutritional, Supplement, Mineral, Fruits, Vitamins

\section{INTRODUCTION}

During times of famine, people suffer for finding food sources and depend on wild food plants for survival [1]. There is a growing interest on the ways to utilize the lesser known plant resources existing in the wild to explore food alternatives. Many indigenous plants are being utilized as food plants, but the studies regarding to their biochemical activities are less [2, 3].

Indigenous fruit trees and shrubs are essential as they provide important nutrients to the diet. The genus Grewia (Family-Tiliaceae) is native to Africa, Asia and Australia and comprises of 150 species with untapped potential. The species of G. tenax can be a useful horticulture plant. It is a small leaved shrub which produces quality fruits growing in semi-arid and sub-humid tropical regions in Rajasthan. The shrub is drought tolerant and can grow on most soil types along the ravine areas, bush land, along watercourses and depressions where moisture is available usually at low elevations. In Sudan it is widely used as a source of iron and used to increase hemoglobin levels by native people. The fruits of $G$. tenax have a number of uses and are most valued for their high nutritive value. They are either eaten fresh or left to dry for later consumption. The fruits juice is reported to be used as refreshing drink. Grewia tenax (Forsk.) Fiori is a much branched shrub distributed in Punjab, Rajasthan and Tamil Nadu [4]. It is a deciduous fruit producing shrub or small tree that may attain a height of 1 to 3 meter. Fruits contribute significantly to the food and energy needs of rural populations [5]. They have good taste that is acceptable to the human palate and are eaten either fresh or left to dry for consumption at a later usage.

Fruits of G. tenax are rich in many nutritional constituents and minerals like iron [6] and used to treat many diseases like anaemia and malaria [7]. Porridge, called Nesha, is usually prepared from the fruit, and is helpful to lactating mothers [8]. The plant contains medicinal properties and can use against bone fracture and swelling [9], trachoma, tonsillitis, infections $[10,11]$ and can be used to prepare ointments [12]. Antibacterial activity and many other medicinal actions are reported earlier [13-17]. The research on exploitation and utilization of Grewia tenax fruits are scanty, therefore, this study to focus on the nutritional potential of this species.

\section{MATERIALS AND METHODS}

Fruits of $G$. tenax were collected from three places: Kailana, Bilara area of Jodhpur and Siwana from Barmer, washed and shade dried. Finally, pulped portion of fruits was separated, dried, ground and stored in a refrigerator.

\section{Proximate analysis}

Moisture, ash, total dietary fibre (TDF), crude protein, sugar (TSS) and fat were analyzed by the methods described in AOAC [18].

\section{Received 12 February 2018; Accepted 04 April 2018 \\ *Corresponding Author \\ Mala Rathore}

Non-Wood Forest Products Division, Arid Forest Research Institute, Jodhpur, India

Email:mala@icfre.org

OThis article is open access and licensed under the terms of the Creative Commons Attribution License (http://creativecommons.org/licenses/by/4.o/) which permits unrestricted, use, distribution and reproduction in any medium, or format for any purpose, even commercially provided the work is properly cited. Attribution - You must give appropriate credit, provide a link to the license, and indicate if changes were made. 


\section{Mineral analysis}

Mineral element contents were determined by wet digestion methods using Atomic Absorption Spectrophotometer (AAS, Perkin Elmer) An acid digestion procedure was used for sample preparation in the determination of elements. A weighed amount of plant material was placed in a digestion tubes (Kjeldahl flasks) and a mixture of $\mathrm{HNO}_{3}$ and $70 \% \mathrm{HClO}_{4}$ was added to each sample and then mixture was heated slowly at a low temperature. After digestion, the samples were diluted to the appropriate volume with deionised water and determined the concentration of the elements of interest. Standards prepared by suitable dilution of the stock standard solutions described in the "Standard conditions" for each element.

\section{RESULTS AND DISCUSSION}

G. tenax is highly drought resistant species that grows wild in the desert but can also tolerate higher rainfall. It is generally found growing in rocky places on hills and slopes. Both Kailana (Jodhpur) and Barmer areas lie in the arid western plain The climate in Siwana is desert type. The average annual temperature in Siwana is $26.9{ }^{\circ} \mathrm{C}$. The average annual rainfall is $333 \mathrm{~mm}$. http://en. climate-data. org/location/286442/. Jodhpur (Kailana area) comes under arid western agroclimatic zone of Rajasthan with rainfall between less than $300 \mathrm{~mm}$. Bilara tehsil of Jodhpur district lies in the transitional plain of luni basin and has semi arid climate with rainfall between 300-500 $\mathrm{mm}$. It is swapped by luni river. Samples were collected from these 3 areas and analysed.

Average moisture content of fruits was found $68.97 \%$ on dry weight basis. Average Seed and pulp weight ratio was found to be as 3.5:5.2. Average weight of G. tenax fruits (50 nos) was found as $9.36 \mathrm{~g}$. The results show that the fruits from Kailana are small. Data on proximate composition of Grewia tenax fruits were given in the Table-1.

The protein was found in the range from $6.02 \pm 0.48$ to $8.4 \pm 1.93 \%$ collected from three different places. The value of ash content was found from $2.7 \pm 0.69$ to $4.73 \pm 1.16 \%$. The level of total soluble sugar for the three places was found in the range from $31.55 \pm 3.27$ to $35.51 \pm 3.55 \%$. Petroleum ether extract (fat) was estimated in the range from $2.12 \pm 0.09$ to $2.66 \pm 0.17 \%$ and level of vitamin $C$ was estimated in the range from $30.24 \pm 8.87$ to $51.1 \pm 7.39$ $\mathrm{mg} / 100 \mathrm{~g}$. On the basis results it can be report that the fruits from Kailana and Siwana area which are drier have higher values than the Bilara area which comes in semiarid region. The results of the protein, TDF, ash and fat content were found very much near or in the range to the study done by Mohammed Elhassan et al. [19] except for the sugar content The sugar content found more in the samples from Jodhpur. Nutritional evaluation of Grewia tenax fruits has also been done by Abdulrahman [20].

\section{Minerals content}

Among the macro elements determined sodium found higher content (mean value $1.49 \pm 0.32 \mathrm{~g} / 100 \mathrm{gm}$ ) than the potassium and potassium found higher content (mean value $1.26 \pm 0.31 \mathrm{~g} / 100 \mathrm{gm}$ ) than calcium (mean value $0.32 \pm 0.03$ $\mathrm{g} / 100 \mathrm{gm})$. Phosphorus showed in traces in these samples. So far as the micro elements determined, copper found in the range from 0.30 to $0.95 \mathrm{mg} / 100 \mathrm{gm}$ for the sample collected from three different places. Zinc found in the range from 1.55 to $2.80 \mathrm{mg} / 100 \mathrm{gm}$. Iron found in the range from 6.10 to 9.45 $\mathrm{mg} / 100 \mathrm{gm}$. Element Manganese found in the range from 0.5 to $0.65 \mathrm{mg} / 100 \mathrm{gm}$. Magnesium showed in the range from 61 to $78.8 \mathrm{mg} / 100 \mathrm{gm}$. Results of minerals analysis showed that iron found in remarkable which is the basis of its use in treatment of anaemia. Cereal powders in the baking industry which are deficient in elements can be fortified with Grewia fruits can enrich the dietary properties.

Table 1: Morphological data of Grewia tenax fruits

\begin{tabular}{llll}
\hline Region & Kailana & Bilara & Siwana \\
\hline Moisture Content & $67.92 \%$ & $70 \%$ & $69 \%$ \\
Diameter (cm) & $0.45-0.70$ & $0.53-0.89$ & $0.50-0.84$ \\
Pulp: Seed & $3.5: 4.8$ & $3: 5$ & $4.1: 5.8$ \\
Wt of 50 fruits (g) & 8.07 & 10.73 & 9.28 \\
Weight of 25 dry fruits (g) & 1.82 & 2.28 & 1.45 \\
\hline
\end{tabular}

Table 2: Proximate composition of fruits of Grewia tenax fruits (Expressed as (\%)on DW basis)

\begin{tabular}{llllll}
\hline Region & Ash content (\%) & Fat (PE Extract \%) & Total Sugar (\%) & Protein (\%) & Vitamin C (mg/100 g) \\
\hline Kailana & $2.7 \pm 0.69$ & $2.34 \pm 0.28$ & $35.51 \pm 3.55$ & $8.4 \pm 1.93$ & $51.1 \pm 7.39$ \\
Bilara & $3.27 \pm 0.93$ & $2.66 \pm 0.17$ & $31.55 \pm 3.27$ & $6.02 \pm 0.48$ & $30.24 \pm 8.87$ \\
Siwana & $4.73 \pm 1.16$ & $2.12 \pm 0.09$ & $31.73 \pm 3.2$ & $6.08 \pm 0.89$ & $56.47 \pm 3.72$ \\
\hline
\end{tabular}

Table 3: Mineral composition of fruits of Grewia tenax from different regions

\begin{tabular}{|c|c|c|c|c|c|c|c|c|c|}
\hline \multirow[t]{2}{*}{ Region } & \multicolumn{5}{|c|}{ Micro elements (mg/100g) } & \multicolumn{4}{|c|}{ Macro elements (g/100 g) } \\
\hline & $\mathbf{C u}$ & Zn & Fe & Mn & Mg & P(mg/10og) & $\mathbf{K}$ & $\mathbf{C a}$ & $\mathbf{N a}$ \\
\hline Kailana & 0.95 & 1.60 & 8.3 & 0.6 & 73.5 & 0.770 & 1.29 & 0.39 & 2.12 \\
\hline Bilara & 0.30 & 2.80 & 6.1 & 0.5 & 61.0 & 1.085 & 0.70 & 0.31 & 1.35 \\
\hline Siwana & 0.35 & 1.55 & 9.45 & 0.65 & 78.8 & 1.305 & 1.79 & 0.28 & 1.02 \\
\hline Mean & $0.53 \pm 0.20$ & $1.98 \pm 0.40$ & $7.95 \pm 0.98$ & $0.58 \pm 0.04$ & $71.1 \pm 5.28$ & $1.05 \pm 0.15$ & $1.26 \pm 0.31$ & $0.32 \pm 0.03$ & $1.49 \pm 0.32$ \\
\hline
\end{tabular}




\section{CONCLUSION}

The approximate chemical composition indicated that Grewia tenax fruits contained good amounts of sugar and protein. Fruits from Kailana, Jodhpur, were found richer in sugar and protein. They are rich source of minerals. From the results, it can be concluded that, the use of Grewia tenax fruits could be highly beneficial to combat nutritional requirement of rural and urban people. The plant can serve as a source of income for the tribal and rural people. So, the conservation and domestication of this plant is highly demanding.

\section{REFERENCES}

1. Leborgne, P., C. Wilkinson, S. Montembaut and M. Tesse-Ververs. Scurvy outbreak in Afghanistan. An investigation by Action Contre la Faim (ACF) and the World Health Organization(WHO). Field Exchange No. 17, November 28-29;2002.

2. Vijayakumari, K., P. Siddhuraju and K. Janardhanan, Nutritional assessment and chemical composition of the lesser known tree legume, Acacia leucophloea. Food Chem., 1994;50:2858.

3. Viano, J., V. Masotti, E. M. Gaydou, P. J. L. Bourreil and G. M. Ghiglione, Compositional characteristics of 10 wild plant legumes from Mediterranean French pastures. J. Agr. Food Chem., 1995;43:680-683.

4. Sharma N. and Patni V. Grewia tenax (Frosk.) Fiori. - A traditional medicinal plant with enormous economic prospective. Asian J. Pharm. Clinic. Res. 2012;5: 28-32.

5. Abdelmutti O. M. S. Biochemically and Nutritional evaluation of famine food of the Sudan. Ph. D. thesis, University of Khartoum, Khartoum, Sudan. 1991.

6. Maydell, H. J. V., Trees and Shrubs of the Sahel. GTZ 6 MBH, Esuborn; 1990.

7. Sulieman, M. S. and A. M. Eldoma, Marketing of Nonwood forest products (Excluding the Gum Arabic) in Sudan. Forest National Corporation (FNC). Ministry of Agriculture, Animal Wealth AndNatural ResourcesKhartoum, Sudan, pp: 3, 10, 20, 30-36;1994.

8. Aschers, Schwf. Grewia fruits used as iron supplement. Nat. Prod. Radiance 2004;3: 368.
9. Shekhawat D, Batra A. House hold remedies of Keshavraipatan tehsil in Bundi district, Rajasthan. Indian J of Traditional Knowledge; 2006;5: 362-367.

10. El Ghazali GEB, El Tohami MS, El Egami AAB. Medicinal plants of the Sudan. In: Medicinal plants of the White Nile provinces. Khartoum University Press, Khartoum; 1994.

11. El Ghazali GEB, El Tohami MS, El Egami AAB, Abdalla WS, Mohammed MG. Medicinal plants of the Sudan. In: Medicinal plants of northern Kordofan. Omdurman Islamic University Printing and Publishing House, Omdurman. 1997.

12. Jaiswal S., Singh S. V., Singh B., Singh H. N. Plants used for tissue healing of animals. Nat. Prod. Radiance; 2004;3: 284-292.

13. Kirtikar K. R. and Basu B. D., Indian Mdicinal Plants. BAsu L. M. and Co., Allahabad, vol. I, p.384;1975.

14. Wealth of India. Raw Materials and Industrial Products, CSIR, New Delhi, Vol. IV, p. 266;1956.

15. Chopra R N, Nayar S L and Chopra I C. Glossary of Indian Medicinal Plants. CSIR, New Delhi, p. 128;1956.

16. Kher Y M El, Salih M H. Investigationof certain plants used in Sudanese folk medicine, Fitoterapia, 1980;51:143-147.

17. Dhar M L, Dhar M M, Dhawan B N, Mehrotra B N, Srimal R C and Tandon J S. Screening of Indian plants for biological activity: Part IV Indian J. Exp. Biol., 1973;11:43.

18. AOAC (Association of Official Analytical Chemist), Official Methods of Analysis, Association of Official Analytical Chemists. 15th Edn., AOAC Press, Gaithersburg, USA. 1990.

19. Mohammed Elhassan G. O. and S. M. Yagi. Nutritional Composition of Grewia Species (Grewia tenax (Forsk.) Fiori, G. flavescens Juss and G. Villosa Willd) Fruits. Adv. J. Food Sci. Technol., 2010;2: 159162.

20. Abdulrahman MDY, Ali AO and Suliman AMA. Nutritional Evaluation of Guddaim Fruits (Grewia tenax) and its Utilization in Ice Cream Production. J. Sci. Tech., 2011;12; 38-43. 